\title{
PERLINDUNGAN HAK CIPTA TERHADAP PEMBAJAKAN KARYA SASTRA NOVEL VERSI E-BOOK DI TOKOPEDIA
}

\author{
Helena Lamtiur Simangunsong, Budi Santoso, Anggita Doramia Lumbanraja \\ Program Studi Magister Kenotariatan, \\ Fakultas Hukum UniversitasDiponegoro \\ Email : helenalamtiur@gmail.com]
}

\begin{abstract}
Tokopedia as one of e-commerce sites has made it easy for every user to make buying and selling transactions online. In Tokopedia there are several sellers who sell e-book versions of literary novels without first asking permission from the creator. This study aims to find out when the e-book version of the literary novel in Tokopedia is said to be a piracy, but also to find out the protection of copyright law and law enforcement efforts in case of copyright infringement. In this study using a normative juridical approach. The results of this study can be concluded that the form of piracy of copyrighted works of e-book novels is to use copy paste technology. Violations in the field of copyright in literary works of e-book novels provide strict sanctions in terms of both civil and criminal. Therefore, government interference cannot be released to eradicate the piracy problem. With the presence of legal protection against copyright is expected to reduce the occurrence of piracy against novels of literary works in the e-book version in Tokopedia.
\end{abstract}

Keywords: piracy; e-book; tokopedia

\begin{abstract}
Abstrak
Tokopedia sebagai salah satu e-commerce telah memberikan kemudahan-kemudahan bagi setiap penggunanya untuk melakukan transaksi jual beli secara online. Di Tokopedia terdapat beberapa pihak penjual yang menjual novel karya sastra versi $e$-book tanpa meminta izin terlebih dahulu dari pencipta. Penelitian ini bertujuan untuk mengetahui kapan novel karya sastra versi $e$-book di Tokopedia dikatakan sebagai suatu pembajakan, selain itu juga untuk mengetahui perlindungan hukum hak cipta serta upaya penegakan hukum apabila terjadi pelanggaran hak cipta. Dalam penelitian ini menggunakan metode pendekatan yuridis normatif. Hasil penelitian dapat disimpulkan bahwa bentuk pembajakan hak cipta karya sastra novel e-book yaitu dengan memanfaatkan teknologi copy paste. Pelanggaran dalam bidang hak cipta karya sastra novel $e$-book memberikan sanksi yang tegas dari segi perdata maupun pidana. Maka dari itu campur tangan pemerintah tidak bisa dilepaskan untuk memberantas masalah pembajakan tersebut. Dengan kehadiran perlindungan hokum terhadap hak cipta diharapkan dapat mengurangi terjadinya pembajakan terhadap novel karya sastra versi $e$-book di Tokopedia.
\end{abstract}

Kata kunci : pembajakan; e-book; tokopedia 


\section{A. Pendahuluan}

Hak Kekayaan Intelektual atau Intelectual Property Rights (selanjutnya akan disebut HKI) khususnya hak cipta adalah hak eksklusif yang diperoleh pencipta terhadap hasil ciptaan atau hasil karya seni yang diciptakannya. Eksistensi HKI ada karena bentuk kreativitas manusia yang dikembangkan atau dipelajari terlebih dahulu sehingga muncullah suatu ide untuk menciptakan sebuah karya yang memiliki manfaat bagi banyak orang. Ruang lingkup HKI salah satunya adalah Hak Cipta. Hak cipta atas karya ciptaan, lahir secara otomatis walaupun ciptaan belum didaftarkan. Menurut Rayfel A. Rantung: "Perlindungan terhadap hak kekayaan intelektual khususnya hak cipta merupakan suatu terobosan tersendiri dalam perkembangan hukum di era modern" (Rantung, 2014).

Pada kamus English Oxford yang dikutip dari buku karanganWarsiman: "Berdasarkan kamus English Oxford, novel adalah prosa fiksi naratif yang amat panjang (biasanya panjangnya mencakup satu jilid atau lebih) yang di dalamnya terdapat karakter dan tindakan yang mewakili kehidupan nyata waktu yang lalu dan yang akan datang dan yang digambarkan dalam suatu plot yang kompleks" (Warsiman, 2017). Menurut Imron Rosidi: "Seorang penulis tidak saja harus menguasai prinsip-prinsip menulis, berwawasan, dan berpengetahuan luas (memadai), menguasai kaidah-kaidah bahasa, terampil menyusun kalimat dalam sebuah paragraph, tetapi juga harusmengetahui prinsip-prinsip berpikir" (Rosidi, 2009). Penulis atau orang yang menciptakan sebuah novel disebut juga dengan novelis atau sastrawan yang bertalenta untuk menulis diberikan oleh Tuhan kepada manusia, kemudian dikembangkan melalui kreativitasnya masing-masing. Sebagai contoh, Rustina Zahra, seorang novelis yang memasarkan novel-novel ciptaannya di Google Play Store dan online marketing lainmelalui self publishing e-book (menerbitkan buku sendiri tanpa bantuan penerbit-penerbit besar), mendapati salah satu e-commerce yaitu Tokopedia yang menjual karyanya tanpa izin ia selaku pencipta dan juga tidak mendapatkan kompensasi atau royalty dari pihak yang membajak karyanya. Pada saat seorang novelis memiliki ide dan dituangkan dalam wujud yang nyata kemudian novelis tersebut melakukan pengumuman dengan cara memasarkan hasil karyanya maka secara otomatis ciptaannya sudah dilindungi oleh hukum. Jadi walaupun ciptaannya tidak didaftarkan atau tidak dicatatkan ke DJKI Kemenkumham (Direktorat Jenderal Kekayaan Intelektual Kementerian Hukum dan Hak Asasi Manusia), ciptaan sudah dilindungi oleh hukum karena sudah diketahui bahwa ciptaan itu adalah ciptaan si penulis tersebut sejak ia melakukan pengumuman. 
Hak cipta itu sendiri memiliki 2 hak pokok yang mendasari bentuk perlindungannya, yaitu hak moral dan hak ekonomi. Hak moral adalah hak yang melindungi natural rights pencipta atau hak untuk diakui sebagai pencipta karena telah menciptakan suatu ciptaan dan hak ini bersifat asasi. Sedangkan hak ekonomi adalah hak yang timbul bagi pencipta untuk mendapatkan keuntungan atau royalty atas ciptaannya yang merupakan hasil dari buah pikirnya dan layak untuk dihargai.

Kedua (2) bentuk perlindungan hukum ini diberikan karena tidak semua orang dapat menciptakan suatu karya yang layak atau yang dapat dinikmati oleh manusia secara maksimal, hanya orang-orang tertentu saja yang dapat mempekerjakan daya berpikir otaknya untuk kemudian dituangkan dalam suatu karya sehingga menghasilkan suatu ciptaan yang bermanfaat. Oleh karena itulah di sini HKI melahirkan sifat eksklusif, di mana hanya orangorang tertentu saja yang bisa mendapatkan hak tersebut. MenurutRiswandidkk: "Hak Eksklusif yang dimaksud yaitu tidak ada pihak lain yang dapat memanfaatkan hak tersebut kecuali dengan izin dari penciptanya atau dibenarkan menurut ketentuan perundang-undangan yang berlaku" (Riswandi, 2017).

Salah satu ciptaan yang merupakan hasil kreativitas manusia adalah ciptaan dalam bidang karya sastra dalam bentuk novel. Undang-UndangNomor 28 Tahun 2014 Tentang Hak Cipta (Selanjutnya akan disebut UUHC 2014), pada Pasal 40 mengatakan bahwa: "Ciptaan yang dilindungi meliputi ciptaan dalam bidang ilmu pengetahuan, seni, dan sastra..."(UndangUndang Nomor 28 Tahun 2014 Tentang Hak Cipta, n.d.).

Menurut Eddy Damian: "Karya Sastra: Ciptaan berupa kata-kata atau gaya bahasa dengan menggunakan bahasa bukan bahasa sehari-hari, yang sering digunakan oleh ahli sastra atau pujangga, pengarang prosa dan puisi atau orang pandai-pandai atau para cendikiawan" (Damian, 2012). Novel karya sastra, pada pengembangan ide cerita, perdalaman karakter atau tokoh, penyampaian pesan-pesan moral yang disampaikan pada novel serta keterampilan untuk memilih rangkaian bahasa menjadi kalimat-kalimat yang memikat dan menghibur para pembaca merupakan hak moral yang erat kaitannya dengan pencipta, dalam hal ini novelis. Novelis juga memiliki hak untuk mendapatkan royalty atas penerbitan, penggandaan, dan pendistribusian novel karya novelis. Merupakan suatu pelanggaran atas hak cipta jika suatu novel diperjualbelikan tanpa sepengetahuan atau izin dari pencipta untuk kepentingan komersil secara pribadi atau kelompok.

Pada era globalisasi seperti sekarangini, karya sastra berbentuk novel dapat ditulis dalam bentuk cetak berupa buku maupun digital. Menurut Muchtar Anshary Hamif Labetum: "Buku 
(apapun jenisnya, baik itu majalah, koran, buku, kitab dan sebagainya) yang selama ini kita jadikan sebagai gudang dari berbagai macam ilmu pengetahuan dan informasi tidak bisa mengelak dari imbas yang diakibatkan dari efek digitalisasi informasi" (Labetubun, 2018). Memasuki zaman yang serba canggih serta meningkatnya kebutuhan akan kemudahankemudahan dalam segala hal, maka terciptalah buku berupa digital yang memberikan kemudahan bagi para penikmat novel untuk membaca novel-novel favoritnya tanpa perlu repot membawa novel berupa buku-buku yang berat untuk dibawa kemana-mana.

Lebih lanjut menurut Ibnu Saefullah: "Buku Digital atau Buku Elektronik (dalam bahasa Inggris dikenal dengan eBook) merupakan sebuah publikasi yang terdiri dari teks, gambar, video, maupun suara dan dipublikasikan dalambentuk digital yang dapat dibaca di komputer maupun perangkat elektronik lainnya."(Saefullah, 2016) Buku digital atau e-book ini terbagi dalam beberapa format, yakni PDF (Portable Doument Format), HTML (Hyper Text Markub Languange), MOBI (Format Mobi Pocket) dan lain-lain. Namun sayangnya kemudahankemudahan yang hadir tersebut disalahgunakan oleh pihak-pihak nakal yang dengan sengaja ataupun tanpa izin dari penerbit atau penulis novel untuk membajak karya sastra-nya, diperjualbelikan di internet untuk kemudian mendapatkan pundi-pundi keuntungan secara sepihak, tanpa menyadari bahwa sebenarnya tindakan ini melanggar hukum. Sehingga terjadilah pelanggaran-pelanggaran hak cipta. Menurut Rehulina Tarigan: "Pelanggaranpelanggaran hak cipta tersebut dapat berupa mengkopi hasil karya cipta dari internet, baik berupa tulisan, music maupun film, dan menyebarluaskannya tanpa izin, menggunakan namanama dari orang terkenal ataupun perusahaan-perusahaan besar sebagainama domain tanpa izin, dan berbagai bentuk pelanggaran lainnya" (Tarigan, 2013).

Melihat pada uraian Pasal 40 UUHC seperti yang telah disebutkan, jelas sekali bahwa novel dalam format e-book merupakan ciptakan yang dilindungi. Pembajakan itu sendiri merupakan pelanggaran etika yang mengalihkan hak ekonomi atau hak moral pencipta tanpa meminta izin terlebih dahulu kepada pencipta atau publisher dengan cara melakukan perbuatan pengumuman atau memperbanyak ciptaan orang lain dengan mengubah atau bahkan tidak mengubah sama sekali wujud ciptaan dengan maksud dan tujuan tertentu.

Perlindungan hukum diberikan dengan tujuan untuk memberikan pengaman yang disusun menjadi instrument untuk mendorong keadilan, kepastian, kemanfaatan dan ketertiban hukum. Perlindungan hukum dapat dibedakan menjadi 2 (dua), yaitu perlindungan hukum preventif dan represif. Menurut Maria Alfons yang dikutip pada buku Edi Setiadi dan Kristian, "Pada perlindungan hukum preventif, kepada masyarakat diberikan kesempatan untuk mengajukan 
keberatan (inspraak) atau mengajukan pendapat sebelum suatu keputusan pemerintah mendapat bentuk yang definitive dan perlindungan yang represif bertujuan untuk menyelesaikan terjadinya sengketa, termasuk penanganannya di lembaga peradilan” (Edi Setiadi, 2017).

Doktrin social control planning merupakan doktrin perlindungan atas hak cipta ini menitik beratkan pada upaya yang dilakukan untuk mengatasi atau mengurangi ketegangan hubungan sosial antara pihak-pihak yang terkait dalam hak cipta untuk kemudian meletakkan kepentingan yang seimbang antara pencipta dengan masyarakat, baik itu perseorangan, kelompok, lembaga-lembaga dan lain-lain dalam konteks yang luas. Artinya suatu hak diberikan bukan untuk memberikan keuntungan sepihak saja tetapi juga memberikan keadilan yang sama antar kedua belah pihak untuk diberikan dan diakui oleh hukum. Doktrin ini juga membantu untuk memberikan apresiasi kepada masyarakat yang memiliki kratifitas untuk kemudian dituangkan kedalam bentuk nyata, yaitu menumbuhkan masyarakat yang berkeadilan dan mendorong prestasi budaya.

Selain teori perlindungan hukum dan social control planning, pada Penjelasan Umum UUHC 2014 paragraf 5 dan 6 dijelaskan bahwa: "Di tingkat Internasional, Indonesia juga telah ikut serta menjadi anggota Agreement Establishing the World Trade Organization (Persetujuan Pembentukan Organisasi Perdagangan Dunia) yang mencakup Trade Related Aspects of Intellectual Property Rights (Persetujuan Tentang Aspek-Aspek Dagang Hak Kekayaan Intelektual) yang selanjutnya disebut TRIPs, melalui Undang-UndangNomor 7 Tahun 1994 dan juga telah meratifikasi Berne Convention for the Protection of Artistic and Literary Works (Konvensi Bern tentang Perlindungan Karya Seni dan Sastra) melaui Keputusan Presiden Nomor 18 Tahun 1997 dan World Intellectual Property Organization Copyright Treaty (Perjanjian Hak Cipta WIPO) yang selanjutnya disebut WCT, melalui Keputusan Presiden Nomor 19 Tahun 1997, sertaWorld Intellectual Property Organization Performances and Phonograms Treaty (Perjanjian Karya-Karya Pertunjukan dan Karya-Karya Fonogram WIPO) yang selanjutnya disebut WPPT, melalui Keputusan Presiden Nomor 74 Tahun 2004.”(Penjelasan Atas Undang-Undang Republik Indonesia Nomor 28 Tahun 2014 Tentang Hak Cipta, n.d.) Dari sini dapat kita lihat bahwa keikutsertaan Indonesia dalam Perjanjian Internasional ini dapat menjadi tonggak perlindungan hukum terhadap Hak Kekayaan Intelektual di Indonesia dan juga sebagai bentuk perhargaan atas Hak Kekayaan Intelektual.

Undang-Undang Dasar Negara Republik Indonesia Tahun 1945 pada Bab 1 Tentang Bentuk dan Kedaulatan pada Pasal 1 menyebutkan bahwa: "Negara Indonesia ialah Negara Kesatuan yang berbentuk Republik.”(Undang-Undang Dasar Negara Republik Indonesia Tahun 
1945, n.d.) Maka adalah suatu hal yang wajar jika di kemudian hari terdapat peraturan perundang-undangan yang mengalami perubahan untuk mengikuti alur perubahan kebutuhan masyarakat. Misalnya adalah Undang-Undang Nomor 19 Tahun 2002 Tentang Hak Cipta yang mengalami pembaharuan pada Undang-Undang Nomor 28 Tahun 2014 Tentang Hak Cipta, dan ini disebutkan pada huruf d. Pada Pasal 41 UUHC 2014 menjelaskan bahwa hasil karya yang belum diwujudkan dalam bentuk nyata tidak dilindungi oleh Undang-Undang. Jadi disini, karya sastra novel walupun tidak dicetak dalam lembaran-lembaran kertas namun dicetak dalam buku elektronik dalam format $e$-book, ia sudah dilindungi oleh undang-undang karena ia berwujud nyata $(e-b o o k)$.

Selama ini masalah pembajakan hak cipta, khususnya di internet tidak hanya meliputi music atau suara dalam bentuk format MP3 (Motion Picture Expert Group Layer 3), video dan digital images. Pembajakan hak cipta juga merambah ke karya sastra novel yang telah di format ke dalam e-book. Jika sebelumnya karya sastra dipasarkan dalam sebuah buku, namun sekarang atas hadirnya internet, seorang penulis novel dapat memasarkan karya-nya dimanapun dan kapanpun melalui jaringan internet. Salah satu e-commerce yaituTokopedia, berbelanja atau berdagang dengan memanfaatkan jaringan internet juga menjadi sasaran pihak-pihak nakal untuk melakukan pembajakan karya sastra novel. Salah satu e-commerce yang digunakan oleh pihak tidak bertanggung jawab ini adalah Tokopedia. Tokopedia merupakan e-commerce pertama di Indonesia tidak hanya menawarkan berbagai jenis produk dengan harga yang terjangkau tapi juga menjadi tempat peredaran produk-produk digital seperti novel dalam bentuk $e$-book.

\section{B. Pembahasan}

\section{Kapan Novel Karya Sastra Versi E-Book Di Tokopedia Dikatakan Sebagai Suatu Pembajakan Terhadap Hak Cipta}

Pembajakan dapat dikatakan merupakan tindakan pencurian yang melanggar hak cipta. Dalam kata lain, kekayaan berupa intelektual pencipta tersebut telah dirampas oleh pihak lain yang dengan sengaja dan tanpa izin pencipta, telah menggandakan dan memperjualbelikan karya cipta si pencipta. Pembajakan novel karya sastra versi e-book telah meresahkan banyak novelis-novelis yang karya-karyanya disebarluaskan dengan mudahnya di jaringan internet dan bahkan diperjualbelikan di berbagai macam situs $e$ commerce, salah satunya adalah Tokopedia. Menurut Antilan Purba: "Karya sastra yang 
menjadi objek ilmu sastra itu bersifat kreatif, imajinatif, intuitif, bertitik tolak pada penghayatan."(Purba, 2010) Oleh karena itu, dalam kegiatan tulis-menulis, sudah tentu seseorang harus memiliki writing skill yang mumpuni untuk menciptakan suatu karya atau dengan kata lain memiliki keterampilan untuk mengekspresikan gagasan-gasasan dari buah pikirannya. Sulit dibayangkan apabila aktivitas kreatif para novelis itu tidak diberikan paying perlindungan hukum sebagai sandaran.

Seorang novelis, yang memasarkan novel-novel karangannya di Tokopedia dalam format buku digital (e-book), tidak kehilangan hak-haknya sebagai seorang pencipta. Namun fenomena online telah "memancing" banyak pihak-pihak nakal yang membajak ciptaannya. Pada awalnya pihak tersebut kenyataannya membeli e-book novel-nya, tetapi kemudian memanfaatkan teknologi copy paste untuk memperbanyak dan menjual ulang novel e-book tersebut untuk mendapatkan keuntungan sepihak melalui Tokopedia. Padahal, dalam Tokopedia telah memiliki ketentuan penggunaan yang sudah seharusnya dipatuhi. Setiap orang yang menggunakan atau memanfaatkan Tokopedia, maka setiap orang itu juga telah menyetujui untuk menyetujui ketentuan-ketentuan penggunaan yang telah ditetapkan oleh Tokopedia. Syarat dan ketentuan ini merupakan suatu bentuk kesepakatan yang dituangkan dalam sebuah perjanjian yang antara Pengguna (baik itu penjual maupun pembeli) denganTokopedia.

Pada syarat dan ketentuannya, Tokopedia mengatur tentang Konten. Konten itu sendiri adalah fitur dan/atau layanan penyampain informasi yang yang tersedia mengenai produk yang ditawarkan oleh penjuala taupun oleh pembeli dalam memberikan komentar mengenai produk. Konten ini dapat berupa gambar atau foto. Gambar atau foto yang digunakan tidak boleh mengandung unsur SARA, diskriminasi, merendahkan atau menyudutkan orang lain, vulgar, bersifat ancaman, beriklan atau melakukan promosi ke situs lain selain situs Tokopedia, atau hal-hal lain yang dapat dianggap tidak sesuai dengan nilai dan norma sosial maupun berdasarkan ketentuan yang ditentukan sendiri oleh Tokopedia. Tokopedia memiliki hak untuk melakukan tindakan yang diperlukan atas pelanggaran konten, anatara lain dengan menghapus konten, moderasi toko, pemblokiran akun dan lain-lain. Pengguna dalam hal ini penjual maupun pembeli bertanggung jawab secara pribadi atas setiap konten yang diunggah di Tokopedia. Artinya, setiap konten dan/atau setiap produk yang dijual tidak boleh melanggar Hak Kekayaan Intelektual seseorang. Situs Tokopedia dengan tegas menjelaskan bahwa penjual dilarang untuk 
menjual produk yang melanggar hak kekayaan intelektual, meliputi hak cipta, merek dagang, atau hak milik lainnya dalam tipe apapun (logo, produk, slogan, dll).

Memang tidak bisa dipungkiri lagi bahwa ciptaan dalam bentuk digital sangat mudah untuk dibajak dan hasil atas pembajakan tersebut juga nyaris tidak dapat dibedakan dengan produkaslinya. Menurut Henry Soelistyo: "Ketika suatu karya tulis telah menjadi ciptaan dengan label Hak Cipta, maka secara yuridis tidak hanya berhak mendapatkan perlindungan Hak Cipta, tetapi juga mendapatkan pengakuan, penghormatan dan penghargaan masyarakat secara sepantasnya.”(Soelistyo, 2012)

Untuk memanfaatkan hasil ciptaan orang lain, terlebih dahulu hendaknya perlu dicermati mengenai apa itu status kepemilikan. Pasal 570 Kitab Undang-Undang Hukum Perdata menyebutkan bahwa: "Hak milik adalah hak untuk menikmati kegunaan sesuatu benda dengan leluasa, dan untuk berbuat bebas terhadap kebendaan itu dengan kedaulatan sepenuhnya, asal tidak bersalahan dengan Undang-Undang, atau peraturan umum yang ditetapkan oleh sesuatu kekuasaan yang berhak menetapkannya, dan tidak mengganggu hak-hak orang lain; kesemuanya itu dengan itu mengurangi kemungkinan akan pencabutan hak itu demi kepentingan umum berdasar atas ketentuan undang-undang dan dengan pembayaran ganti rugi."(Kitab Undang-Undang Hukum Perdata, n.d.) Menurut Muhammad Djumhana dan Djubaellah, "Dari ketentuanPasal 570 KUH Perdata tersebut kita bisa menarik kesimpulan bahwa setiap hak milik mempunyai unsur:

a. Kemampuan untuk menikmati atas benda atau hak yang menjadi objek hak milik tersebut.

b. Kemampuan untuk mengawasi atau menguasai benda yang menjadi objek hak milik itu, misalnya, untuk mengalihkan hak milik itu kepada orang lain atau memusnahkannya.”(Muhammad Djumhana, 2014)

Hak cipta itu timbul secara otomatis untuk pencipta sejak ciptaan itu ada dalam wujud yang nyata (e-book novel) kemudian diumumkan. Keadaan yang demikian tidak mempengaruhi atau mengurangi hak-hak pencipta yang melekat secara konkret walaupun novel-nya dijual dalam format buku digital (e-book).

\section{Perlindungan Hukum Bagi Pencipta Terhadap Pembajakan Novel Karya Sastra Versi E-Book Di Tokopedia}

Tokopedia digunakan untuk bertransaksi jual beli dengan cara penjual memanfaatkan situs tersebut sebagai showroom atau online shop-nya. Legal issue dalam 
hal ini adalah perlindungan hukum terhadap pencipta dalam hal hak kekayaan intelektual yang telah diatur dalam Pasal 40 Undang-Undang Nomor 28 Tahun 2014 Tentang Hak Cipta, serta Pasal 23-26 Undang-Undang Nomor 11 Tahun 2008 Tentang Informasi dan Transaksi Elektronik (selanjutnya disebut UU ITE 2008). Pasal 25 UU ITE 2008 menyebutkan: "Informasi elektronik dan/atau Dokumen Elektronik yang disusun menjadi karya intelektual, situs internet, dan karya intelektual yang ada di dalamnya dilindungi sebagai Hak Kekayaan Intelektual berdasarkan ketentuan Peraturan PerundangUndangan.” (Undang-Undang Nomor 11 Tahun 2008 Tentang Informasi dan Transaksi Elektronik, n.d.) Namun secara das sein masih terdapat permasalahan hukum yang tidak dapat terselesaikan dalam hubungannya perlindungan hukum dalam pembajakan atas ciptaannya di Tokopedia, yaitu ada bebarapa toko online yang menjual sebuah ciptaan tanpa meminta izin terlebih dahulu ke pencipta selaku orang yang memiliki hak ekonomi dan hak moral terhadap hasil ciptaannya tersebut.

Pembajakan sebagaimana UUHC 2014 Pasal 1 ayat 23 menyebutkan adalah tindakan penggandaan ciptaan secara tidak sah dan pendistribusian barang hasil penggandaan dimaksud secara luas untuk memperoleh keuntungan ekonomi. Menurut Andi Ardiyan Mustakim: "Jadi, suatu kasus masuk dalam kategori pembajakan jika memenuhi dua unsur, yaitu penggandaan tanpa izin dan pendistribusiannya untuk memperoleh keuntungan komersial."(Mustakim, 2017)

Rustina Zahra, seorang novelis yang penulis hubungi pada 16 Oktober 2019 mengatakan bahwa ada beberapa toko-toko online di Tokopedia yang telah menjual novel digital-nya dengan harga yang jauh lebih murah dari harga jual yang memang pantas ia dapatkan untuk menghargai jerih payahnya dan toko-toko online ini tidak meminta izin padanya terlebih dahulu. Toko online tersebut adalah Cherries Shiop, SuperstarNovel dan Sabitah Sh0p.

Menurut Nahrowi: "Secara tradisional, Hak Cipta telah diterapkan ke dalam bukubuku, tetapi sekarang Hak Cipta telah meluas dan mencakup perlindungan atas karya sastra, drama, karya musik dan artistik, termasuk rekaman suara, penyiaran suara film dan televisi dan program komputer."(Nahrowi, 2014) Dengan maraknya pembajakan yang semakin meresahkan pencipta, sebenarnya terdapat salah satu cara yang dapat dilakukan oleh pencipta sendiri untuk melindungi ciptaannya dari pembajakan. Yaitu dengan cara mengamankan buku digital ciptaannya melalui platform Digital Rights Managements (DRM) atau Manajemen Hak Digital. DRM adalah sebuah teknologi yang mengatur akses 
oleh pihak penerbit atau pencipta untuk melakukan pembatasan atas penggunaan suatu media atau karya digital. Teknologi DRM ini membuat $e$-book hanya dapat terbaca pada satu device digital saja dan jika ingin dipindahkan keperangkat lain tidak akan bisa. Hal ini untuk mencegah penggandaan atau pembajakan $e$-book tersebut.

Berbagai materi yang ada di jaringan internet tetap dilindungi oleh hak cipta. Menurut Yusran Isnaini: "Hak cipta sebagai bentuk perlindungan yang diberikan oleh negara, secara substansi merupakan sebuah jaminan terhadap hak eksklusif yang dimiliki oleh pencipta dan atau pemegang hak untuk mengeksploitasi karya mereka secara komersil.’(Isnaini, 2019) Pada prinsipnya karya cipta dalam bentuk konvensional seperti novel yang dicetak dalam sebuah buku, tidak akan akan kehilangan hak ciptanya walaupun kemudian diubah ke dalam bentuk digital (e-book). Sebaliknya sebuah novel dalam bentuk e-book juga dilindungi oleh hak cipta sama halnya jika novel tersebut dicetak ke dalam sebuah buku pada lembaran-lembaran kertas.

Terdapat cara untuk "menghukum" pihak yang melanggar hak cipta bagi pencipta yang mendapati hasil ciptaannya dibajak, seperti yang dijelaskan pada Pasal 55 UUHC 2014 yaitu dapat melapor kepada Menteri Hukum dan Hak Asasi Manusia untuk menutup sebagian atau seluruh konten yang melanggar Hak Cipta dalam sistem elektronik atau menjadikan layanan sistem elektronik tidak dapat diakses. Menteri yang dimaksud disini adalah Menteri Hukum dan Hak Asasi Manusia. Perihal mengenai pelaporannya terdapat pada Peraturan Bersama Menteri Hukum dan Hak Asasi Manusia Republik Indonesia dan Menteri Komunikasi dan Informatika Nomor 14 Tahun 2015 dan Nomor 26 Tahun 2015 Tentang Pelaksanaan Penutupan Konten dan/atau Hak Akses Pengguna Pelanggaran Hak Cipta dan/atau Hak Terkait dalam Sistem Elektronik. Pada Pasal 2 ayat 1 jelas menyebutkan: "Pelanggaran Hak Cipta dan/atau Hak Terkait dapat dilaporkan kepada menteri yang menyelenggarakan urusan pemerintahan di bidang hukum.”(Peraturan Bersama Menteri Hukum dan Hak Asasi Manusia Republik Indonesia dan Menteri Komunikasi dan Informatika Nomor 14 Tahun 2015 dan Nomor 26 Tahun 2015 Tentang Pelaksanaan Penutupan Konten dan/atau Hak Akses Pengguna Pelanggaran Hak Cipta dan/atau Hak, n.d.)

Tokopedia memiliki perjanjian pilihan hukum pada syarat dan ketentuan pengguna. Perjanjian ini diatur oleh dan ditafsirkan sesuai dengan hukum yang ada di Indonesia tanpa memperhatikan pertentangan aturan hukum. Setiap pengguna diwajibkan untuk menyetujui bahwa tindakan hukum apapun atau sengketa yang timbul dari, berhubungan dengan, atau 
berada dalam cara apapun berhubungan dengan situs dan/atau perjanjian pilihan hukum ini akan diselesaikan secara eksklusif dalam pengadilan Republik Indonesia.

Rustina Zahra selaku novelis ataupun novelis-novelis lainnya, jika mendapati adanya konten penawaran produk yang ditawarkan di Tokopedia atau dalam kata lain menjual buku karangan pencipta tanpa izin, maka dapat mengajukan laporan atas pelanggaran hak cipta. Seperti yang dapat dilihat pada situs Tokopedia, Pencipta wajib melampirkan bukti bahwa konten penawaran produk yang dilaporkan tersebut melanggar hak cipta, seperti surat pencatatan ciptaan yang diterbitkan oleh Direktorat Jenderal Kekayaan Intelektual, bukti kepemilikan ciptaan (surat pernyataan, surat kuasa, bukti pengalihan, dsb), perjanjian dengan penerbit buku dan bukti pendukung lainnya. Pelaporan atas pelanggaran hak cipta tidak hanya terbatas pada penjualan buku tanpa izin, namun juga meliputi penggunaan foto atau gambar tanpa izin, penjualan software ciptaan tanpa izin, dan bentuk-bentuk pelanggaran-pelanggaran hak cipta lainnya tanpa izin sesuai dengan peraturan perundang-undangan yang berlaku.

Wadah yang ada di Indonesia mengenai sengketa hak cipta sesuai dengan UUHC 2014, itu bisa diselesaikan secara perdata maupun pidana. Dalam hal karya ciptaan digunakan untuk kepentingan komersial tanpa izin pencipta terlebih dahulu, maka pencipta bisa memilih. Jika yang pencipta tuju adalah kompensasi, yang dalam hal ini adalah penggantian biaya dari karya-karya tersebut maka pencipta dapat menempuh jalur perdata. Dari awal, pencipta berhak melakukan somasi atau peringatan terlebih dahulu kepada orang yang melanggar hak cipta dan jika pihak tersebut tidak menghiraukan, maka pencipta bisa menggugat pihak tersebut di pengadilan hingga nantinya pengadilan akan memutuskan bahwa ia bersalah atau tidak dan perlu atau tidak ia membayar kompensasi terhadap pencipta. Tetapi jika yang ingin dituju oleh pencipta bukan kompensasi, dalam artian ingin memberikan "pelajaran" karena telah membajak ciptaannya, maka pencipta dapat menempuh jalur pidana, dimana pencipta melaporkan si pelanggar hak cipta tersebut kepada pihak penegak hukum, dalam hal ini melapor ke DJKI Kemenkumham atau juga bisa langsung ke pihak kepolisian. Apabila terbukti bahwa ia melanggar hak cipta dengan menggunakan hasil ciptaan orang lain secara komersial tanpa izin dari pemegang hak cipta, maka ia bisa diberikan sanksi penjara bersama putusan hakim.

UUHC 2014 juga menegaskan bahwa barang siapa telah terbukti telah melanggar hak cipta, maka akan diberikan sanksi pidana dan sanksi perdata. Pada Pasal 113 ayat 3 dikatakan, dapat dipidana dengan penjara paling lama 4 (empat) tahun dan/atau pidana 
denda paling banyak Rp 1.000.000.000,00. Dari ketentuan ini maka aparat penegak hukum dapat melakukan tindakan terhadap perbuatan pembajakan agar segala kerugian-kerugian yang ditimbulkan bisa diminimalisir.

\section{Simpulan}

Perlindungan hukum hak cipta terhadap pembajakan novel karya sastra versi $e$-book di Tokopedia dituangkan dalam Undang-Undang Nomor 28 Tahun 2014 Tentang Hak Cipta. Hak cipta memberikan perlindungan hukum jika suatu ide telah terwujud ke dalam bentuk yang nyata. Umumnya bentuk pembajakan novel karya sastra versi e-book dilakukan dengan menggunakan teknologi, yaitu copy paste. Motif pembajakan adalah untuk mendapatkan keuntungan ekonomi secara sepihak.

Upaya penegakan hukum terhadap pembajakan hak cipta novel karya sastra versi $e$-book diatur dalam Undang-Undang Nomor28 Tahun 2014 Tentang Hak Cipta, dimana upaya penegakan hukumnya oleh pemerintah dengan memberikan sanksi pidana dan sanksi perdata dengan tuntutan berupa ganti rugi. Pada Pasal 113 ayat 3 Undang-Undang Nomor 28 Tahun 2014 Tentang HakCipta, dikatakan bahwa Pemerintah memiliki peran untuk menegakkan hukum hak cipta terhadap pembajakan novel karya sastra versi $e$-book di Tokopedia dengan memberikan sanksi yang tegas berupa pidana penjara paling lama 4 (empat) tahun dan/atau pidana denda paling banyak Rp 1.000.000.000,00 (satu miliar rupiah).

\section{DAFTAR PUSTAKA}

\section{Buku}

Damian, E. (2012). Glosarium Hak Cita dan Hak Terkait. PT Alumni.

Edi Setiadi, K. (2017). Sistem Peradilan Pidana Terpadu dan Sistem Penegakan Hukum di Indonesia. Kencana.

Isnaini, Y. (2019). Mengenal Hak Cipta Melalui Tanya Jawab dan Contoh Kasus. Pradipta Pustaka Media.

Muhammad Djumhana, D. (2014). Hak Milik Intelektual Sejarah, Teori, dan Praktiknya di Indonesia. PT Citra Aditya Bakti.

Purba, A. (2010). Pengantar Ilmu Sastra. USU Press.

Riswandi, B. A. (2017). Pembatasan dan Pengecualian Hak Cipta di Era Digital. PT Citra Aditya Bakti. 
Rosidi, I. (2009). Menulis... Siapa Takut? Panduan bagi Penulis Pemula. Penerbit Kanisius.

Saefullah, I. (2016). Langkah Cepat Menerbitkan Buku Digital Secara Mandiri. Kainoe Books.

Soelistyo, H. (2012). Plagiarisme: Pelanggaran Hak Cipta dan Etika. Penerbit Kanisius.

Warsiman. (2017). Pengantar Pembelajaran Sastra: Sajian dan Kajian Hasil Riset. UB Press.

\section{Artikel Jurnal}

Labetubun, M. A. H. (2018). Aspek Hukum Hak Cipta Terhadap Buku Elektronik (E-BOOK) Sebagai Karya Kekayaan Intelektual. Jurnal Ilmiah Fakultas Hukum Universitas Pattimura, 24(2), 139.

Nahrowi. (2014). Plagiat Dan Pembajakan Karya Cipta Dalam Hak Kekayaan Intelektual. Salam; Jurnal Filsafat Dan Budaya Hukum, 229.

Rantung, R. A. (2014). Hak Cipta Dalam Jaringan Internet Ditinjau Dari Undang-Undang Nomor 19 Tahun 2002 Tentang Hak Cipta. Jurnal Hukum Unsrat, II(1), 101-102.

Tarigan, R. (2013). Pelanggaran Hak Cipta Melalui Internet (Studi Kasus: Itar-Tass Agency Melawan Russian Kurier Agency. Flat Justitia Jurnal Ilmu Hukum, 7(1), 2.

\section{Tesis}

Mustakim, A. A. (2017). Pembajakan Soft Copy Karya Tulis Ilmiah (Studi Terhadap Pelanggaran Hak Cipta Dalam Hukum Positif dan Hukum Islam di Yogyakarta). Universitas Islam Negeri Sunan Kalijaga.

\section{Undang-undang dan Peraturan}

Undang-Undang Dasar Negara Republik Indonesia Tahun 1945.

Undang-Undang Nomor 11 Tahun 2008 Tentang Informasi dan Transaksi Elektronik.

Undang-Undang Nomor 28 Tahun 2014 Tentang Hak Cipta. (n.d.)

Kitab Undang-Undang Hukum Perdata.

Penjelasan Atas Undang-Undang Republik Indonesia Nomor 28 Tahun 2014 Tentang Hak Cipta.

Peraturan Bersama Menteri Hukum dan Hak Asasi Manusia Republik Indonesia dan Menteri Komunikasi dan Informatika Nomor 14 Tahun 2015 dan Nomor 26 Tahun 2015 Tentang Pelaksanaan Penutupan Konten dan/atau Hak Akses Pengguna Pelanggaran Hak Cipta dan/atau Hak. 